\title{
UPPER STREAM OF THE RIVER SANA - JUSTIFICATION OF BUILDING HYDRO POWER PLANTS WITH RESPECTIVE ACCUMULATIONS
}

DOI: http://dx.doi.org/10.18509/GBP.2019.17

UDC: 556.53.06:621.311.21(497.6)

\author{
Vesna Rajcevic \\ Tanja Mislicki-Tomic \\ Čedomir Crnogorac
}

Faculty of Natural Sciences and Mathematics, University of Banja Luka,

Republic of Srpska, Bosnia and Herzegovina

\begin{abstract}
The river basins in the territory of the Republic of Srpska are a part of the basins stretching across the entity borderline, even across the borders of Bosnia and Herzegovina on the whole. Exploiting and managing waters in upper and middle streams respectively may have significant impact on the conditions of exploiting waters in lower sections of basins as well. Processes that are dominant in the former sections are directly reflected on those taking place in the latter ones. Given the position of basins in the territory of Bosnia and Herzegovina and the Republic of Srpska respectively, there is a pronounced necessity for researching into the matter, in accordance with current trends in the world and our geographic area. The existing engineering-geological, hydrological, and geomorphological data on the basin of the upper stream of the Sana show that this area is suitable in terms of building hydro power plants with respective accumulations. A hydro power plant, or multiple plants, in the upper stream of the Sana, featuring poly-functional contents, is going to contribute to the economic development of the area, all with the preservation and enrichment of the environment at the same time.
\end{abstract}

Key words: valley of the Sana, upper stream of the river Sana, building hydro power plants, accumulations, the economic development

\section{INTRODUCTION}

The River Sana. The River Sana is the most significant tributary of the River Una, with the mouth at the town of Novi Grad. If the River Vrbas is the dominant watercourse of the river network of the north-eastern part of the municipality of Mrkonjic Grad, then the same role is reserved for the River Sana on its western borders. The Sana springs from several karstic springs (scattered springs). From the springhead to the elevation point 353 (mouth of the stream of Semis), the Sana has scored the dominant crag. The overall length of the river is $146.2 \mathrm{~km}$ (measured along the line of talveg), with the section referring to the municipality of Mrkonjic Grad being $5.4 \mathrm{~km}$ long, and the overall surface area of the basin is $3,369.40 \mathrm{~km}^{2}$.

\section{Tributaries of the Sana in its spring section.}

One of the most significant aspects of the environment in terms of economic geography is the energy sector, that is, techniques of application and exploitation of various forms of energy. It is now a global issue, which implies energy resources, their consumption, but also the security of energy infrastructure and systems. With regard to accessibility and exploitation of certain sources of energy in modern-day world, the assessment of 
influence of certain energy products on the environment plays the main role. For these reasons, there is an increased interest in renewable energy sources, such as wind energy, solar energy, biomass and waste, geothermal energy, and hydro energy [7].

As for the Republic of Srpska, there has been a trend of building hydro-power plants since the beginning of this century, in particular small and micro ones (SHP).

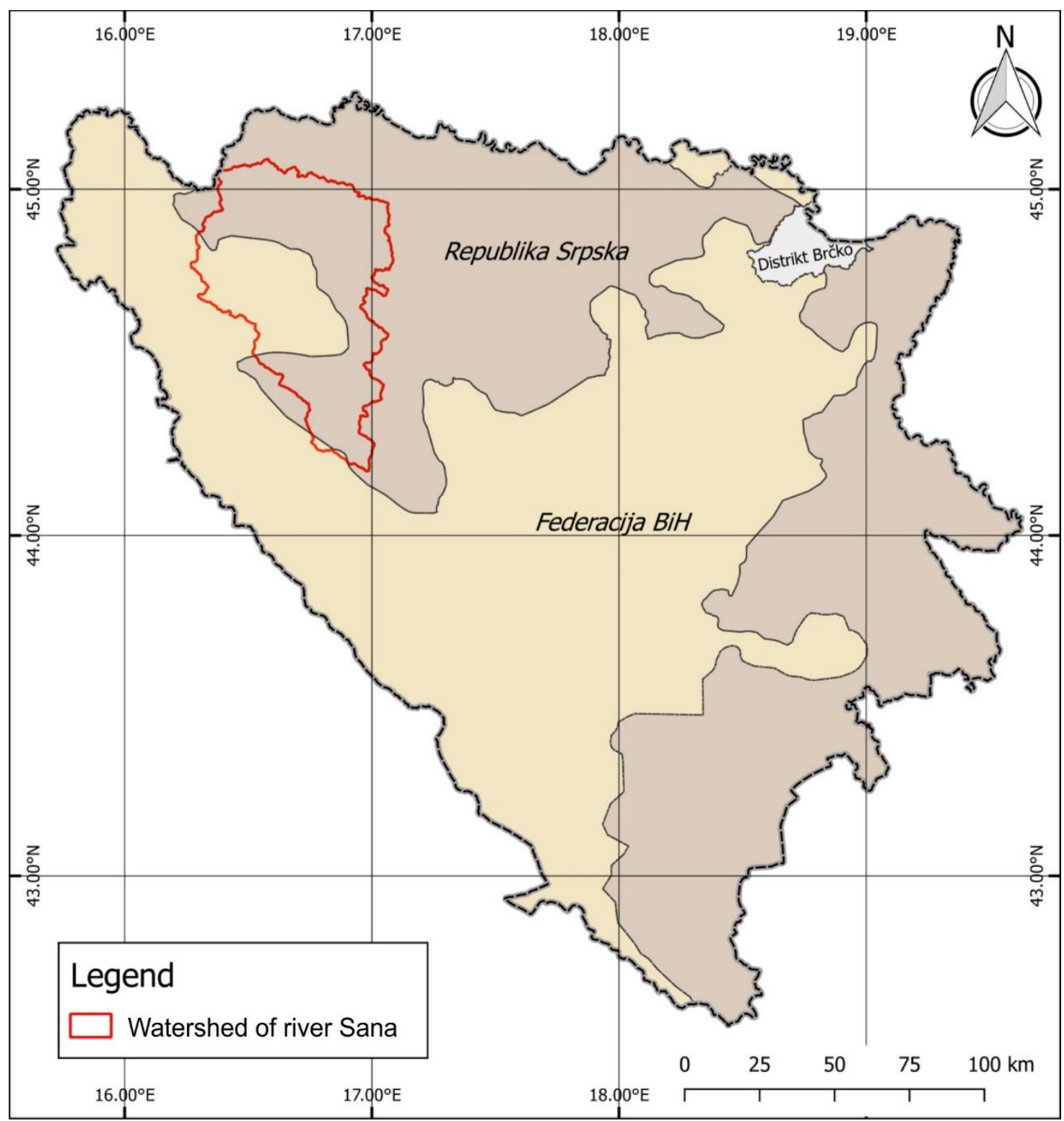

Figure 1. The position of the Sana River basin in the Republic of Srpska and Bosnia and Herzegovina

Spatial planning solutions and the role of SHPs in the environment. There are numerous barriers in terms of building SHPs, such as administrative, social, technical, financial, institutional, legislative, environmental, and ecological (The Study of Impact on the Environment). With regard to administrative ones, one can single out non-issuance of urban planning permits and long deadlines set for concessionaires to collect valid documentation for building an SHP. With regard to this issue, the most common excuse of the local authorities in the Republic of Srpska is the claim that SHP facilities have not been accounted for in terms of spatial planning documentation. The fact remains that numerous municipalities in this entity delay the design of such documentation due to lack 
of financial funds, which is the reason why a number of concession requests in the Republic of Srpska is still not in hand. In 2014, the Commission for Concessions of the Republic of Srpska stated that most of the conclusions of the Government of the Republic of Srpska regarding SHP concessions had not been realized [7].

Table 1. Share of hydro power plants in electricity production in the Republic of Srpska in the period of 2008-2011 (Power Utility Company of the Republic of Srpska) [12]

\begin{tabular}{|c|c|c|c|c|c|c|c|c|}
\hline$\downarrow$ Manufacturers & \multicolumn{3}{|c|}{ Production of electricity $(\mathrm{GWh})$} & \multicolumn{3}{c|}{ Production of electricity (\%) } \\
\hline Years $\rightarrow$ & 2008. & 2009. & 2010. & 2011. & 2008. & 2009. & 2010. & 2011. \\
\hline Gacko termal plant & 1563.25 & 1434.02 & 1540.28 & 1613.53 & 30.72 & 25.47 & 24.94 & 30.45 \\
\hline Ugljevik termal plant & 1531.17 & 1559.00 & 1315.72 & 1836.22 & 30.09 & 27.68 & 21.31 & 34.66 \\
\hline Termal plants overall & 3094.42 & 2993.02 & 2586.00 & 3449.75 & 60.81 & 53.15 & 46.25 & 65.11 \\
\hline Trebišnjica hydro power plants & 863.91 & 1236.64 & 1610.01 & 927.40 & 16.44 & 21.96 & 26.07 & 17.50 \\
\hline Drina hydro power plants & 814.36 & 1054.14 & 1283.05 & 717.37 & 16.00 & 18.72 & 20.78 & 13.54 \\
\hline Vrbas hydro poer plants & 256.71 & 286.58 & 353.85 & 174.46 & 5.04 & 50.08 & 5.73 & 3.29 \\
\hline Hydro power plants overall & 1934.98 & 2577.36 & 3246.91 & 1819.23 & 38.03 & 45.77 & 52.59 & 34.34 \\
\hline DHE and MHE & 58.71 & 60.04 & 71.12 & 28.61 & 1.153 & 1.066 & 1.150 & 0.540 \\
\hline Overall production & 5088.11 & 5630.42 & 6174.03 & 5297.59 & 100.00 & 100.00 & 100.00 & 100.00 \\
\hline
\end{tabular}

According to the data available, there have not been complex research into the water management of basins of majority of rivers in the Republic of Srpska (except for the rivers of Drina, Bosna, Vrbas, and Una), and the similar situation is with most of watercourses in the same area. Any possible, but necessary future research into the matter and subsequent documentation derived from it (programme elements) is going to present solid foundation for the guidelines concerning future exploitation of the river network in the Republic of Srpska in terms of spatial planning activities. The following is the list of necessary data in terms of designing and constructing an SHP (with a respective accumulation): engineering-geological and hydro-geological features of the basin, morphometric, morphological, hydrological, climatic, geomorphological geophysical, and geochemical properties [12].

Table 2. Share of hydro power plants in electricity production in the Republic of Srpska in the period of 2008-2011 (Indexes)

(Power Utility Company of the Republic of Srpska) [12]

\begin{tabular}{|c|c|c|c|c|c|c|c|c|c|c|c|}
\hline \multicolumn{4}{|c|}{$\begin{array}{c}\text { Production of electricity } \\
\text { (Thermal) - GWh }\end{array}$} & \multicolumn{4}{c|}{$\begin{array}{c}\text { Production of electricity } \\
\text { (Hydro) - GWh }\end{array}$} & \multicolumn{4}{c|}{ INDEXES } \\
\hline 1 & 2 & 3 & 4 & 5 & 6 & 7 & 8 & $1: 5$ & $2: 6$ & $3: 7$ & $4: 8$ \\
\hline 2008. & 2009. & 2010. & 2011. & 2008. & 2009. & 2010. & 2011. & 159.9 & 116.2 & 79.6 & 189.6 \\
\hline 3094.42 & 2993.02 & 2586.00 & 3449.75 & 1934.98 & 2577.36 & 3246.91 & 1819.23 & & & & \\
\hline
\end{tabular}

When the water regime of the Sana River is concerned, it can be said to belong to the pluvio-nival regime, the Posavina (area related to the Sava River) sub-variance, with maximum water regimes in March, April, May, and November, and minimum one in August and September [8].

\section{THEORETICAL-METHODOLOGICAL BASIS OF RESEARCH}

The previous research conducted in the geographic area of the Republic of Srpska and in the basin of the Sana River relate to the range and role of the rivers, river network, and river systems of the Republic of Srpska in the energy balance regarding renewable energy sources [7]. 
The research primarily aims at analyzing the ways the hydro energy sector in the Republic of Srpska uses waters of the Sana River, with the complementary task of researching into the extent to which its hydro power potential participates in the structure of renewable energy sources by the year of 2020, in accordance with the requirements/demands of the EU. The specific aims of this research are the following: hydro energy potential of the Sana River as a user of waters in the Republic of Srpska, share of its future hydro power plants in the consumption of electrical energy of the Republic of Srpska, along with an analysis of exploitation of hydro energy systems and possibilities of hydro energy development on bigger/transit and smaller/autochthonous watercourses of the Republic of Srpska [7][12].

In this paper, we use a number of scientific and research methods, both theoretical and practical. In terms of data processing, we rely on analytical (mathematical-statistical), synthetic, and comparative methods. The fieldwork research of the Sana River basin were done in the period of 2000-2017, and they comprised recognizing the basin areas and determining certain features of the basin. The respective photo-documentation is part of the fieldwork research.

\section{GEOLOGICAL STRUCTURE-ENGINEERING-GEOLOGICAL FEATURES}

With regard to the geological structure of the basin area of the upper stream of the Sana River (from the spring to the locality of Velija - mouth of the Ribnik River into the Sana), there are several lithological complexes, from Permo-Triassicic clastites and metamorphites, over Mesozoic clastic and carbonate, to rocks of Neogene lake basins and Quaternary sediments. The tectonic complex of the area of the upper stream of the Sana belongs to the central Dinaric Alps, more precisely to the structural-facies unit of GrmecSisa, that is, the Vrbanja-Lisina block. The north-eastern border of the structural-facial unit of Grmec-Sisa is the dislocation-drift of Kljuc, the southern one the dislocation of Jasenovi potoci [9][10].

The northern border of the Vrbanja-Lisina block is the cover of Kljuc, which is concealed by the drift of the structural-facies unit of Manjaca-Zmijanje. The cleft of Lisina is on the western side, while Neogene sediments cover the eastern border. In fact, according to the geological division of M. Komatina (1983), the basin area of the upper stream of the Sana belongs to the region of internal karst (expansion of Earth's surface) [3]. It should be emphasized that the aforementioned geographic area, as part of the Dinaric Alps range, has been, in terms of geotectonic analyses, the subject of research of a number of geologists, with various schemes being interpreted.

The area of the valley of the upper stream of the Sana, from the spring to the locality of Slatina (locality of possible hydro power plant) is formed by limestone sediments [8]. Downstream, the valley is mostly formed by Upper Triassicic limestone rocks, with occasional Permo-Triassicic ones.

When the crag of Prizrengrad is concerned, it is a relatively lithologically homogeneous limestone block (Lower Cretaceous lime-stones - K1), with light and light-grey limestones represented as well [2][6]. The sediments of the lower parts of the Lower Cretaceous are represented by micrites, marly micrites, and dolomites. The marl $-\mathrm{a}$ sedimentary rock of a mixed clay-carbonate mixture; it contains $50-80 \% \mathrm{CaCO}_{3}$ and $\mathrm{MgCO}_{3}$, and $20-50 \%$ of clay-like material. It is widely spread in nature, in all geological periods, starting form the Proteozoic [8]. 


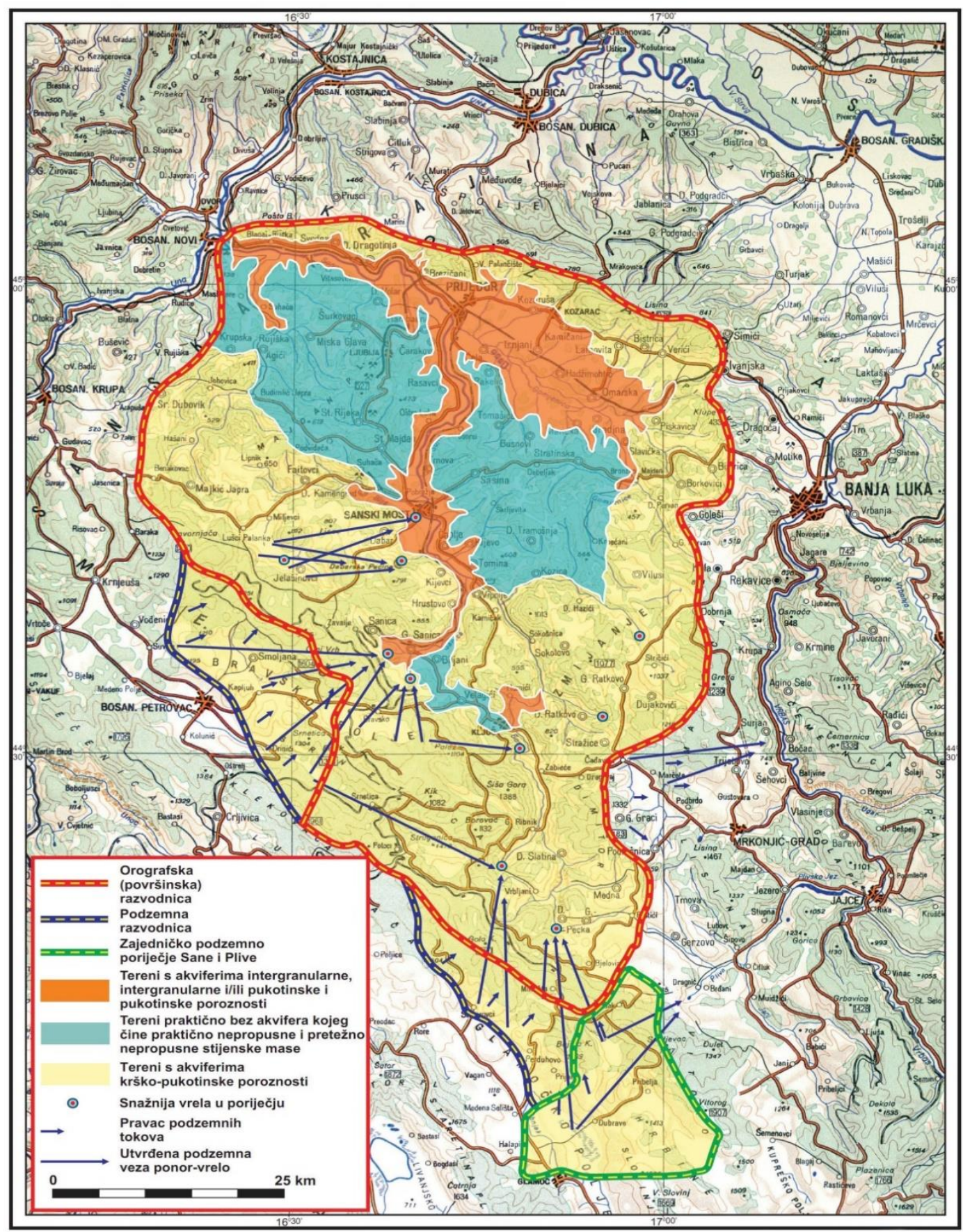

Figure 2. Hydrogeological categorisation of the Sana River basin [8]

1. Orographic (surface) drainage divide, 2. Hydrogeologic (underground) drainage divide, 3. Common watershed of Sana and Pliva river basins, 4. Permeable rocks with intergranular, intergranular and/or fracture and fracture porosity, 5. Mainly impermeable rocks or poorly permeable rocks, 6. Karst-fracture porosity unit, 7. High-yield springs, 8. General direction of underground flow, 9. Proven underground connection sinkhole @ spring

Micrites and marly micrites are built from micro and crypto-crystal calcites. The calcite is one of the most important calcium minerals, and it is a calcium-carbonate in terms of its chemical structure. The calcite dominating the Sana basin is formed through sedimentation, and it builds significant limestone masses in the upper stream of the Sana [5]. The basic mass in the crag of Prizrengrad is dispersed in places by clay-marly 
substance, with the deposits of 500-700 $\mathrm{m}$ in thickness. In most cases, there are bank layers, partially fractured [1]. The valley of the Sana River, upstream of the crag of Prizrengrad, from the mouth of Medljanska River to the spring, is formed by lime-stones (at least the Apt.-Alb K1). These deposits are around $500 \mathrm{~m}$ thick, represented in welllayered and slab-like grey lime-stones, containing no significant macrofossils. The analyses conducted show that there are sea snails (Nerinea) in them, then algae and foraminifera (class of amoeboid protists). Given the aforementioned, one can conclude that all the Low Cretaceous lime-stones in the valley of the Sana River are thick or bank layered, with only occasional occurrence (on the left bank in the crag of Prizrengrad) of massive lime-stones. The field research in the area show that layers vary in thickness from 20 to $40 \mathrm{~cm}$, while the inclines differ in both direction and size, with inclines ranging 10$50^{\circ}$ and layers stretching perpendicularly to the valley of the Sana [11].

\section{Engineering-geological characteristics of the upper stream of the Sana River}

The research into the engineering-geological characteristics of the geographic area of the upper stream of the Sana show that it is built by bound carbonate rocks [8]. Carbonates are a mineral class, natural salts of carbonic acid (dolomite, magnesite, malachite, siderite etc), and they build layers of sedimentary and metamorphic rocks (lime-stones, dolomites, marble etc). Stony carbonate rocks are mainly represented by layered and massive Low Cretaceous lime-stones $\left({ }^{1} \mathrm{~K}^{3}\right.$ and $\left.{ }^{2} \mathrm{~K}^{4}\right)$. On the slopes of the crag of Prizrengrad, there are 1

accumulations, formed by rough and large material (accumulations of products generated by rock destruction moving down the slope) [11].

It is evident that the deep-cut segments of the crag on this stretch of the Sana are on defined carbonate/limestone blocks. The basic rock, in the form of bank layered or massive Low Cretaceous lime-stones is a disrupted/discontinuous middle. There are no signs of greater splits or split zones, but it should be researched in the future [3].

In essence, the rock mass of the researched area (crag) is stable and suitable for building hydro power facilities. This is an initial assessment, which can be modified by a number of parametres in later stages of the research.

Taking into consideration possible digging into the basic limestone rock, there is a high possibility of exploiting that rock mass in civil engineering.

Engineering-geological conditions for designing and construction of hydro power plants. In order to design and construct the 'Slatina' hydro power plant with a respective accumulation and, possibly, the 'Lekici' hydro power plant with respective facilities, detailed geological research is going to be necessary. According to provisions of the Law on Geological Research (Official Gazette of the Socialist Republic of Bosnia and Herzegovina, issues 35/79 and 15/90), the Law on Spatial Planning (Official Gazette of the Republic of Srpska, issue 84/02), the Rulebook on Contents of Programme, Project, and Feasibility Study of Geological Research (Official Gazette of the Socialist Republic of Bosnia and Herzegovina, issue 25/85), and the Rulebook on Technical Normatives for Designing and Constructing respectively it is necessary to analyze the following:

a) data on engineering-geological and hydro-geological characteristics;

b)data on geomechanical and geotechnical characteristics, and

c) data on geophysical and geochemical research [11].

Light grey micro-crystal lime-stones with algae; layered to bank-layered, of split porosity Layered lime-stones with traces of dolomite; layered to bank-layered, of split porosity 
Final discussion. In case the construction of the plant is set in motion, all digging activities are going to be done in solid rock - carbonates; the intended category is VI, with the digging done by means of blasting. The slope of the dig is generally assessed as stable, the inclination ranging from 5:1 to 10:1.

The rock mass in this section of the River Sana is rather solid and without visible damage. However, it should be stressed that structural relations have not been sufficiently researched into.

The engineering-geological relations on the spots intended for the barrier (the accumulation of Prizrengrad) are almost identical to the accumulation areas. We estimate that the rock masses are adequate for building foundations of barrier objects (dams). This should be further verified through detailed geological research, in case the whole project is approved for construction [11].

\section{ANALYSIS OF THE SPLIT COMPLEX}

The analysis of the split complex has been conducted based on an immediate field research and mapping, along with application of geostatic methods and, partly, the available documentation. As far as our analyses are concerned, the basic element of water porosity are splits.

There are diastromes registered on the spots of intended barriers, as well as in the areas of future accumulations - inter-layer splits running parallel with the layers, separating one from another. Also, there are diaclases registered as well, split cutting through multiple layers, with no relative movements along them.

The field research proves that the area intended for the accumulation is mostly built from moderately-cracked limestone. The moderately-cracked zone is dominated by the complex of splits with different elements of inclination. Concerning the poorly-cracked zone of massive lime-stones, on the left bank of the Sana, there are rare cracks and compressed cracks, which brings to light the fact that the split structure of a rock mass is essential for its mechanical characteristics [11].

The river valley in the flooding area of the intended accumulation. The area in which the accumulation of the 'Slatina' hydro power plant (provisional title) should be formed is a deep-cut crag, that is, a narrow, deep valley of steep slopes in mountainous relief, with dominant elevation points of Sokolovaca $(841 \mathrm{~m})$ and Rnjava glava $(610 \mathrm{~m})$ on the left bank and Prizren $(712 \mathrm{~m})$ on the right one. The crag is dominated by forest vegetation of little practical and economic value, with no settlements or road infrastructure. All geological and petrographic analyses confirm the stability of the rock mass, and there are no major rock-slides registered nor any other indications of instability. With regard to engineering-geological and hydro-geological characteristics, they show that this section of the Sana features favourable conditions for building a hydro power plant with a respective accumulation. In essence, this facility could have a poly-functional purpose: regulation of the flow, flood protection, water supply, irrigation, fishery, water sports, tourism and recreation etc [11].

\section{HYDRO-GEOLOGICAL CHARACTERISTICS}

Given the numerous previous research, the hydro-geological characteristics of the upper stream of the Sana and its spring have been thoroughly documented. A section of the basin lies in the area of carbonate sediments of Mesozoic, so we focus on defining the position of hydro-geological watersheds. The River Sana and its upper stream serve the 
function of the regional basis, that is, the main recipient of waters in their surrounding. As far as its spring is concerned, there are several karstic springheads in the vicinity of the village of Donja Pecka, with the following registered capacity:

- maximum: $50 \mathrm{~m}^{3} / \mathrm{sec}$;

- medium: $8 \mathrm{~m}^{3} / \mathrm{sec}$;

- minimum: $1.7 \mathrm{~m}^{3} / \mathrm{sec}$.

\section{Springheads of the Sana and upper stream of the river.}

The basin area of the springheads of the Sana is defined by a series of specific elements, one of which is a pronounced hydro-geological function of the dolomites of the Upper Triassic. In terms of aerial distribution and water circulation in nature, that function is assumed by layers of minor lake basins (Vrbljani, basin of Pecka). The second one is orientation distribution of hydrologically important clefts, as well as a great extent and depth of karstification. The basin area of the Sana is bordered by hydro-geological waterheds.

\section{Hydro-geological functions of rock masses.}

According to hydro-geological regionalization of rock masses, the researched area can be divided into three separated units. The first one encompasses southern, south-western, eastern, and parts of the northern basin. The second one is made up of porous rocks with inter/granular, inter/granular and/or split, and split porosity. The third unit is made up of terrains with non-porous rocks of virtually and predominantly non-porous rocks, thus making the infiltration of atmospheric waters rather slow [8].

With regard to hydro geology, the carbonate rocks building the waterbed and lateral, deeply-cut sections of the valley of the upper stream serve the function of a collector (draining pipe) and a reservoir of split-cavernous type of porosity. The hydro-geological function of an area depends more on the tectonic and hypsometric position of lime-stone masses, but, to a lesser extent, on their porous ability as well [8].

The geological profile, from the chasm in the field of Glamocko polje, from where the water is drained towards the springhead of the Sana, show that the overturned anticline, with sediments from Paleozoic and Early Triassic, completely obstructs the drainage of water, assuming the role of a hydro insulator. On the other hand, waters that are drained through numerous cracks in Cretaceous lime-stones, drifted on Triassic sediments, are accumulated above them in various cracks and emerge as surface waters in the area of the springhead of the Sana.

\section{ANALYSIS OF THE IMPACT OF INTENDED ACCUMULATIONS IN THE UPPER STREAM OF THE RIVER SANA ON THE ENVIRONMENT}

Previous research into the environment of the upper stream of the Sana, concerning vegetation, land, geological surface, climate, demographic characteristics, anthropogenic influences on the geographic area, historical heritage, geoheritage and alike, might be defined as fragmentary. It is clear that there are relevant data missing in order for a more complex assessment of the aforementioned ecosystem to be made [4].

In the valley of the Sana, especially in its upper stream and its tributaries, in the cracks of carbonate rocks and in multiple colluvial sediments, a number of endemic species have allegedly been registered, although without any specifications as regards a concrete plant or animal. If this is confirmed through a scientific research, it will be necessary to provide for their protection and a field research range for further scientific and educational 
activities in the area. With regard to this, certain geo-ecological profiles of Low Cretaceous layers present significant scientific challenges [4].

Therefore, we think that, on the one hand, the construction of the future 'Slatina' hydro power plant, with the respective accumulation, in accordance with the relevant legislation and technical criteria, should provide for the preservation of the environment and even enrich it when possible. On the other hand, it is a vital water management facility in the area, in terms of irrigation of agricultural land and protection against uncontrolled flood waves. Given all that, a referent project is needed to account for detailed analyses concerning the possible influence of the aforementioned plant on the environment, serving as a model of how the environment of a certain geographic area should be protected [11].

Although it is possible for the negative impacts to affect partly the flora and fauna of the area as well (no human settlements in the vicinity of the planed construction site), we do not regard them as a serious threat, given their temporary character and the protective measures undertaken.

\section{CONCLUSION}

With regard to the aforementioned area, the process of karstification lags behind that of erosion, rendering an insignificant risk of accumulation forming. Furthermore, the research have shown that ground waters correspond with the riverbed. Overall, the physico-mechanical characteristics of rock masses within the geological structure of the terrain are suitable for designing hydro energy facilities. In addition, the lime-stone masses are stable and adequately waterproof. However, there is a possibility of the existence of less favourable local zones, but this, after a detailed research, can be overcome by means of design and construction.

\section{REFERENCES}

[1] Ahac, A, Papes, J, and Rajić, V., Basic geological map 1 : 100 000, Index for the Glamoc section, SGZ, Belgrade, 1978 pp. 52

[2] Bosnjak, R., The Sana River Valley, Gazette of the Geographical Society, issue 32, Belgrade, 1952

[3] Ivkovic, A, Komatina, M., Hydrogeological map and index for the Socialist Federal Republic of Yugoslavia (1:500000 scale), Federal Geological Institute, Belgrade, 1983

[4] Lakusic, R., Ecological characteristics of the Una-Sana region and possibilities of their improvement, rational exploitation, and efficient protection, Institute for Architecture and Urbanism, Sarajevo, 1985

[5] Milanovic, P., Risk of building hydro-technical objects and accumulations in karst areas, Directions of development of geotechncs - an international conference, Faculty of Mining and Geology - Department of Geotechnics, Belgrade, 1996

[6] Papes, J, Srdic, R., General hydrogeological relations on the territory of Bosnia and Herzegovina, The Karst of Yugoslavia, issue 10, Zagreb, 1978, pp 93-102

[7] Rajcević, V, Crnogorac, C., Hydrogeothermal potentials in the function of renewable energy in the Republic of Srpska, GEOGRAPHIC SOCIETY OF THE REPUBLIC OF SRPSKA, Volume XVII, Banja Luka, 2013, pp 121-133

[8] Spahic, M, Temimovic, E, Jahic, H., HYDROGEOLOGICAL CATEGORISATION OF THE SANA RIVER, Acta geographica Croatica, Volumen 39, Zagreb, 2012, pp 65-75 
[9] Vrhovcic, J, Vujnovic, L, and Mojicevic, M., Basic geological map and index for the Kljuc section, Geoengineering, Sarajevo, 1983

[10] Vrhovcic, J, Vujnovic, L, and Mojicevic, M., Basic geological map and index for the Kljuc section, Designing hydro power plants, Geoengineering, Institute for Geology, Sarajevo, 19691976

[11] Vujacic, M, Crnogorac, C., Engineering-geological characteristics of the upper stream of the Sana River as foundation for designing hydro power plants with respective accumulations (The Lekici hydro power plant, the Slatina hydro power plant), research paper, Banja Luka, 2004

[12] Dakic, P, Dakic, V, Hydro energy potential of the Republic of Srpska, Book of proceedings, Academy of Arts and sciences of the Republic of Srpska, Banja Luka, 2008, pp 43-424 